\title{
Judicial Intervention to Corporate Governance: Causes and Approaches
}

\author{
Professor Sheng Xuan Guo \\ Northwest University of Political Science and Law, China
}

\section{Introduction}

A corporation is a legal person with group personality created by the law and is considered to have the freedom of autonomy as a subject of private law. A corporation is also considered as shareholders' tool to pursue profit just like a kite flown by shareholders especially substantial shareholders. A corporation is considered as a contractual combination, a gathering place of stakeholders and constituting a cell of society. A corporation is described as a Utopia. ...With different interest claims, subjects such as management, shareholders, directors, creditors, employees and others who coexist in a corporation through the certain formal structure of corporate governance.

Whether according to opinion which demands building a corporate governance structure with shareholder's rights as the core, or according to corporate contract theory, which stresses that multiple stakeholders should be subject to a common governance, a corporation always depends on articles of association to realize its autonomy. It seems to be an independent kingdom with a high-degree of autonomy relying on a rights and obligations structure between corporate stakeholders that is constructed by the inner system of board of shareholders, board of directors, managers and board of supervisors. Based on either theoretical analysis or empirical study, the feasance or nonfeasance of company, shareholders, directors and other subjects usually leads to low efficiency, invalidity, injustice and inequality and unbalanced rights during corporate governance. However, the corporate autonomy mechanism is not able to correct itself.

The various company laws in all countries inordinately improve corporate governance through shareholders' rights protection mechanisms by which shareholders protect their or the corporation's rights and ensure that a company runs efficiently through direct action and representative action. However, judicial intervention under this circumstance, just like other private rights protected by public power by virtue of judicial intervention, does not belong within the scope of issues discussed in

Copyright (C) 2015 Victoria University. This document has been published as part of the Journal of Law and Governance in both online and print formats. Educational and non-profit institutions are granted a non-exclusive licence to utilise this document in whole or in part for personal or classroom use without fee, provided that correct attribution and citation are made and this copyright statement is reproduced. Any other usage is prohibited without the express permission of the publisher. the article. The judicial intervention to corporate governance discussed in this text, beyond the concept of "judicial nonintervention to corporate governance", refers to the judicial involvement and correction to the unjust, unfair and invalid or expired corporate performance shielded by the rights stipulated by the articles of association and resolutions of shareholder meetings affecting a corporation's operations (inner affairs management). 
Judicial intervention includes the review and correction of discriminatory ${ }^{1}$ and unequal corporate regulations, the resolution of obstacles to convening shareholder meetings and director meetings, special service or recall of company directors, the "tyranny" of prevention of majority decisions regarding capital expenditure which hampers justice, the prevention of director's illegal behavior, the precaution of harmful connected transaction, etc. Such problems are difficult solve through inner settlement mechanisms within the scope of corporate governance, and therefore judicial intervention is required to make judgments and correction that will uphold justice and fairness.

Justice can satisfy the "need" of corporate governance, but the question is how to "supply" it? In other words, what is the approach of judicial intervention to corporate governance? Specifically, how to effectively construct a litigation system, judgment methods and the limitations to abide by in judicial intervention in corporate governance in the present judicial system? Should courts change their approach of judicial intervention from negative and hysteretic judgment to positive and beforehand intervention? Should the limited intervention turn to a broader scope? How can justice guarantee the company formal and healthy operation during its intervention to corporate governance? How can the effectiveness of the intervention be ensured? Accordingly, there are so many problems need researching. Due to the limitation of space and the author's capability, the article makes an outline and preliminary discussion of the approach of judicial intervention to corporate governance.

\section{Corporate governance needs judicial intervention}

A system is a kind of evolutionary order. The historical track along which common law gradually established the limits to judicial intervention in a company through legal precedents has proved that corporate governance needs judicial intervention. The cause of the need can be analyzed from various perspectives $^{2}$ and this article tries to analyze and explain the necessity and importance of judicial intervention to corporate governance through combining two concepts of corporate governanceshareholder autonomy and stakeholder co-governance with the corporate effectiveness goal.

1. The need to protect the rights of minority shareholder under shareholder autonomy.

The traditional theory of company law insists on company law theory which considers that a company's legal personality is just its superficial characteristic and shareholders are undertakers of owner's equity and therefore the fundamental corporate nature is that of a shareholders' investment tool. Shareholders occupy the core positions as company owners in corporate autonomy and hence modern company autonomy is shareholder's autonomy in essence. The emergence and development of a company and company systems take place with shareholders as the core pushing power, and the function performance of the company system mainly depends on the realization of shareholder autonomy. However, the corporate governance with shareholder autonomy at its center indicates that the majority shareholders' opinions will be adopted to deal with company business and management

\footnotetext{
${ }^{1}$ For instance, "the sales regulation that clients in Putian, Fujian province are recorded as dishonest clients" referred to in the arbitration between Alibaba and its employee in 2014, and the inner recruitment regulations with differentiation and discrimination about gender, health, education background, etc.

${ }^{2}$ Some scholars point out the necessity of legal interference into corporate governance based on multiple demands of power balance, the privatization of public law, reducing organization cost, improving long-run bargain, adjusting interest conflicts and enhancing cooperation between economic subjects. See Ren Zongli \& Yu Qun, "The Legitimacy of Law Governing into the Corporate Governance from the Perspective of Legal Philosophy”.(2003)8 Journal of Shaoguan College.
} 
affairs. Therefore, the majority shareholders in a company have the final decision-making right and their decision on any matter made through an ordinary or special resolution shall be binding on all shareholders. As to the matter decided by majority voting, the minority shareholders have to comply with the majority shareholders' will. ${ }^{3}$

According to theoretical study and practical observation, the majority shareholders take advantage of their controlling position to suppress the minority shareholders, to avoid certain items in articles of association or to gain the maximum interest and wealth from the company for themselves. When the majority shareholders abuse the so-called democratic rights arbitrarily the company will not ensure an even bargain and shareholders' individual rights will not be respected. The abuse of majority rule shows more obviously in a non-listed company, because "In a closed setting, the corporate norms of centralized control and majority rule can become instruments of oppression. Some decisions vitally important to participants, such as their employment and salary, are left to the board of directors to make. When harmony between participants disappears, the minority participants may find that the majority interest can manage the affairs of the corporation in unexpected ways. The minority dominating the board can terminate minority shareholders' employment as officers, thereby diminishing the return on their investments. The corporation may not pay dividends to any shareholders to avoid double taxation, yet the majority shareholders will continue to receive a return on their investment in the form of salary or perhaps rent or interest on money loaned to the corporation. Indeed, these amounts may increase after the minority shareholders are excluded.

Traditionally, the minority shareholders have had no way to protect themselves against such an occurrence. If minority shareholders attempt to establish a contract for protection against this possibility, such as by agreements that the minority shareholder retain a corporate office and a salary, courts earlier this century struck down the agreement as an unlawful interference with the unfettered discretion of directors. The performance of the corporate form further compounds the minority shareholder's dilemma. Without a job and in the absence of dividends, the minority shareholder may face an indefinite future with no return on the capital he or she contribution to the enterprise. The majority may even be able to deny the minority shareholders any return in the long run by siphoning off corporate assets in the form of high salaries or rents, insulated from judicial review by the business judgment rule. In addition, the majority may force the minority to leave the company with unjust excuses."

There are many state-owned firms and family businesses among listed firms in China mainland. The traditional centralized economic system and cultural atmosphere have resulted in a highly centralized ownership structure in the listed companies. Moreover, the listed firms have a large number of shareholders who are retail investors. A majority of these can exchange shares frequently that is their collective "hitch-hiking" impacts on a corporation's share price, and negatively on corporate governance. All of these factors lead to the ubiquity of "insider control" in listed firms. In these firms, the controlling shareholders enjoy far more practical privileges than the minority shareholders, and they not only own the shareholders' rights but also manipulate and control the

\footnotetext{
${ }^{3}$ See Joseph E. U. Abugu, "A Comparative Analysis of The Extent of Judicial Discretion In Minority Pro-tection Litigation; The United Kingdom and United States," International Company and Commercial l.aw Review (2007) pp. 181-183.

${ }^{4}$ R. B. Thompson, "The Shareholder's Cause of Action for Oppression ", (1993) 48 Bus. Law. p. 703.
} 
practice of the rights of supervisors, directors, even operators. By taking advantage of their control on the general meeting of shareholders and the board of directors, the big shareholders reach resolutions so as to achieve their special purposes while disregarding, even infringing the rights and benefits of small investors. These sorts of disputes frequently occur in the listed companies in respect to affiliate transactions, and annexation of firms' properties.

The board of directors loses its independent status, which makes it difficult to achieve a decision independently and at the same time, fails to perform its function of supervision. ${ }^{5}$ There is an obvious shortcoming of company law; in response, it is reasonable to use resolutions of the shareholders' meetings to replace the common-interest rights of shareholders when the law lacks a legitimate basis to replace and suppress the self-interest actions of shareholders.

2. The demand of balanced protection for multiple interests under common governance

Based on the company contract theory ${ }^{6}$, a company is a nexus of contracts between shareholders, managers, employees, suppliers, customers, creditors and others. This paper argues that the company stakeholders should participate in its governance. For this purpose, it is necessary to build channels and platforms where multiple stakeholders can voice their demands and requirements; for staff, creditors and shareholders representing the interests of disadvantaged organizations, a third party is necessary to judge and correct unjust autonomous conduct, and properly protect the interests of each party.

A company is an individual pursuing profit from head to toe, or alternatively is a miniature cell in society that shoulders responsibility for workers, customers, community members, and the government; the debate will continue. In fact, the theory that shareholders are the center of corporate governance has dominated governance in mainland China. Company legislation and justice are deeply influenced by it. ${ }^{7}$

The shortcomings of company law are: since the relationships between controlling shareholders and minority shareholders, companies and directors, shareholders and directors, debtors and companies, shareholders and directors, and companies and staff are very complicated, and the habitual thought of governing companies centers on shareholders, company law neither emphasizes the rights or problems of many shareholders, nor sets an effective relief system. It is necessary to depend on and learn from some concepts and values in Anglo-American Law such as "fiduciary obligation" "judgment of

\footnotetext{
${ }^{5}$ See Peng Zhenming, Lu Jian, Judiciary Intervention and Inner Governance of Listed Companies: the Dilemma of Localization and its Solutions, Social Science Front 2011(05), PP.197

${ }^{6}$ See Michael C Jensen \& William H Meckling, Theory of the Firm: Managerial Behavior, Agency Costs and Ownership Structure, Journal of Financial Economics V.3.NO.4.PP.305-360 ; Frank H Easterbrook and Daniel R Fischel, The Corporate Contract, Columbia Law Review. Vol.89 P.1418; Easterbrcok \& Fisehel, The Economic Structure of Corporate law, Harvard University Press, 1991; Lucian Arye Bebchuk: The Debate on Contractual Freedom In Corporate Law, Columbia Law Review, V01.89, No.7, PP 1395-1415.

${ }^{7}$ Some scholars think, the principle of autonomy of private law performance for shareholder autonomy in company law. See Jiang Daxing, Jin Jianfeng, On civil law character of company law -View position to examine the judicial position, Journal of Nanjing University (Philosophy, Humanities and Social Sciences),No.1,2005, PP - 39-46; Chang Jian: Foundation, Value and Achievement of shareholders autonomy,2009, No.6, PP.49-62.In legislation, the legislative purpose of the company law and company organization structure, both embodies the shareholder autonomy theory; On the judiciary, the mainland court is generally not involved in internal disputes referee, is the concentrated reflection of shareholder autonomy theory.
} 
operators" and "business judgment", so that judges can discretionarily judge the legitimacy of shareholders and protect their rights and benefits in certain cases. In the Chinese mainland judicial system, it may be through the way of a Supreme Court case to guide the Primary Court firstly, and then by way of judicial interpretation, and ultimately by modifying the Companies Act, to determine the principles of judicial intervention on corporate governance, ways and necessary restrictions.

\section{The demand of pursuing effective order in company governance}

The realization of lawful order in company governance is through unification between company autonomy and national enforcement (legislative regulation and judicial intervention). The judicial intervention in company management substantially reflects the state's will to correct company autonomy. Cheffins, a Canadian expert on company law analyzes judicial intervention in the operation of company from the dual goals of promoting efficiency and realizing fairness. ${ }^{8}$ When it comes to the goal of efficiency, firstly, it is necessary for the judiciary to get intervention since the problem of incomplete information, including the problem of systematic information and unbalanced information, may cause the existence of a gap in a company contract, fraud in contract system, and a "lemons market", resulting in the waste of company resources; secondly, the cost of private conclusion to a contract is very huge, and the contracting cost can be reduced through mandatory law texts of the state; and thirdly, national enforcement can solve the problem of negative "externalization" as well as collective actions (game theory explains the reason why an individual trader practices in a way that can maximize his own benefits but obtain a result without efficiency). As for a fair goal, national enforcement can appropriately prevent those fraudulent, misleading, and coercive conduct while paying more attention to the underprivileged ones. Moreover, the actual controllers of the company will have to shoulder strict fiduciary duties so that fair treatment to small and big shareholders and balanced interests among them can be realized. Furthermore, national enforcement can also restrict disordered competition and create a market mechanism with fair competition, ensuring that market participants observe the basic moral codes.

\section{Feasibility of judiciary intervention into company management}

\section{Judiciary function including an exterior safeguard for company management}

As a recheck system, company management covers different system structures inside and outside companies. The judiciary and administration together constitute an exterior monitoring mechanism of company management. Judiciary organizations and legal systems represented by the organizations are also an exterior safeguard mechanism of company management. Judiciary organizations represent the will of the state to judge company autonomy (private) conducts, correct autonomy conducts of injustice and imbalanced interests, safeguard the rights of relevant parties, and maintain a sound order of company autonomy. Jurisdiction intervention to company autonomy in the way of civil action can safeguard the rights, coordinate benefits relationships inside companies and the relationship between companies and the outside, and promote company autonomy in ways that are both orderly and efficient.

\footnotetext{
${ }^{8}$ See (Canadian) Brlan R.Cheffins, "Company Law: Theory, Structure, and Operation", translated by Lin Weihua, etc., Law Press China (2001), PP.135-168.
} 
(1) Rights safeguard function of jurisdiction (intervention to a rights safeguard and relief type)

Rights are divided into substantial rights and procedural rights (relief rights). "Where there are rights, there is protection; there will be no rights if remedies do not exist". The purpose of civil action lies in protection for the substantial rights by offering necessary remedies to the substantial rights. ${ }^{9}$ On the other hand, the purpose of civil action also lies in settling disputes, so the system of civil action will become meaningless if disputes between individuals fail to be settlrd. ${ }^{10}$ Disputes are objects of the jurisdiction function and safeguarding rights is the function of judiciary.

There is a rights chain in companies, and shareholders' rights are the base for other rights in the companies. It is through shareholders' conduct that a group personality of companies is established. The separation of the shareholders' rights and companies' rights maintain their own independent personality. The best organization and structure mode for maintaining companies' independent personality should be the establishment of a powerful board of directors not a board of shareholders. The members in a board of directors do not have to be shareholders themselves.

Only by an operations group which is not comprised of shareholders completely, can the other personality subject — companies' benefits--- be taken into consideration independently. ${ }^{11}$ Besides some main linking points in the rights chain of companies such as shareholders, companies, and directors, there are debtors, staff in companies and other rights-holders. The "ecological balance" of companies' rights will be destroyed if the rights of each chain are too strong or too weak. Therefore, the remedy on rights is an exterior practice to maintain the ecological balance of companies' rights. The fundamental standards on evaluating the effectiveness of the jurisdiction's intervention to company management are whether disputes among relevant parties in company law get settled, and whether the rights get safeguarded.

(2) Order maintenance function of jurisdiction (intervention in an order maintenance type)

Civil action enables parties to obtain safeguards when successful, so that the parties can predict the result of planning and performing in accordance with the norms and regulations of substantial law. Self-discipline in compliance results in an overall stable social life. ${ }^{12}$ Company autonomy is a private order inside and outside companies supported by a company management structure. Good company management is a fair, orderly, and effective autonomous structural system formed by multiple rightsholders such as companies, shareholders, directors, managers, debtors, staffs. Jurisdiction's intervention in company management can correct the malfunction and disorder of company autonomy besides settling disputes and safeguarding rights.

\footnotetext{
(Japanese) Shindō Kōji,"New Civil Procedural Law", Lin Feng, Law Press China (2008), p.3

${ }^{0}$ (Japanese) Shindō Kōji,"New Civil Procedural Law", Lin Feng, Law Press China (2008), p.7 Jiang Daxing, "Concepts of Company Law and Explanations", Law Press China (2009), p.142.

${ }^{2}$ See (Japanese) Shindō Kōji, "New Civil Procedural Law”, Lin Feng, Law Press China (2008), p.7
} 
2. Jurisdiction with activity.

As a part of a corporate governance system, the judicial body gives effective and timely intervention to corporate autonomy, and leads to a perfect corporate governance structure so as to achieve the goal of justice, fairness, and effectiveness for corporate governance.

Judicial activism, a product of the common law system, is a term surrounding the historical relationship of judicial reviews and constitutions. The Black's Law Dictionary defines judicial activism as "a philosophy of judicial decision-making whereby judges allow their personal views about public policy, among other factors, to guide their decisions, usually suggesting that adherents of this philosophy tend to make constitutional violations and are willing to ignore precedent." 13 There exists a trade-off relationship between judicial activism and judicial restraint. The application of judicial activism is a confirmation on judicial discretion, which allows judges to extract rules and bridge law gaps to ensure the integration of specific application of laws and justice. Lord Denning had explained the complementary function of judicial discretion for legal limits, and described the basic principle to be followed by judicial discretion as "Judges must not change the texture of laws but ironing the folds". ${ }^{14}$

Conservative judicial concepts need to be alert while judicial activism is followed. One of the conservative judicial concepts is that the court should not intervene in corporate internal management, corporate operations and decision-making activities, or corporate business judgments. Jurisdiction pursues a judicial criterion of "ruling follows disputes". "The court shall not reject to adjudicate civil disputes on the ground of no provision provided in law" is the basic norms of civil justice. The conception that justice never intervenes in corporate affairs does not accord with the principle of final judicial adjudication. Another conservative judicial concept is that a judicial view on corporate internal affairs is equal to intervening in corporate management, which is similar to the governmental over-controlling of companies in China's planned economy era. Jurisdiction plays a different role from that of administration. Jurisdiction should respect corporate operations, which does not mean jurisdiction needs to be away from corporate operations such as administration.

\section{Wary Judicial intervention to the company affairs.}

Judicial intervention in corporate autonomy has different intervention initiatives based on different affairs and fields. The company law has prescribed the adjusting affairs of prohibitions on which judges can be actively involved. When intervening in corporate autonomy related to business judgment, judges should be wary of the intervention, because judges are not specialized in commercial activities. If shareholders appeal corporate internal affairs to the court for settlement before going through the remedy procedures within the corporation the court should reject the request to intervene.

\footnotetext{
${ }^{13}$ Bryan A. Garner, Black.s Law Dictionary (8th edition), West Thomson Bussiness(2004), P862.

${ }^{14}$ (Britain)Lord Denning: The Discipline of Law .Translated by Liu Yong'an, Yang Baikui, Ding Jian ,Law Press China(1999),P.112.
} 
In the field of corporate governance disputes, judicial activism exceeds the connotation of review by public power, and is added to with a new connotation of intervention in the private order. It needs to deal with both judicial discretion under the uncertainty of company law, and the range and mechanisms of judicial intervention to corporate business. Judicial intervention to corporate autonomy is limited. "Judicial expansion and discretion have been throughout the development history of company laws in the Anglo-American countries", ${ }^{15}$ which is worthy summarizing. Active judicial intervention often occurs when corporate governance faces risks, and aims to uphold the social justice and correct market disordering. In the US judicial activism is mostly used by the legal realism school created by Holmes. When a judge deals with a specific dispute, a balance needs to be made between codes tightly held in his left hand and some integrated factors such as specific case contents, social influences, mortality, ethics, policies, and legal principles touched by his right hand. Based on this balance, a final decision is made. Therefore, when a judge is involved in corporate governance affairs in the name of judicial review, he /she has to adhere to the principles of legality review first while a rationality review is second, and a formal examination first while a substantial examination second, so as to be wary of corporate affairs, respect corporate autonomy, and maintain corporate ordering.

Judicial intervention to corporate governance could prevent some shareholders' opportunism. If the cost of suing, or judicial remedies without suing, is low, it may cause the disadvantages associated with opportunism while easing the rights protection of minority stockholders. Once justice intervenes in corporate disputes, the corporate management must make efforts to deal with the intervention, causing some damages to the whole corporation's benefits. Considering this risk, many shareholders may make use of this risk to blackmail a corporation in exchange for improper benefits.

Under the guidance of shareholder autonomy, company law is gradually inclined to take a court as the center. However, it does not mean that the court can make judgments for shareholders or infringe the corporate autonomous rights of shareholders. The concept of shareholder autonomy suggests that "individuals are the best judges of their own interests". The court should respect shareholders' arrangements on corporate affairs in judicial review, and the judicial intervention to corporate affairs should insist on the principle of limited intervention. As the last defensive line of personal rights, judicial remedy is of great importance for defending personal rights. The defense of personal rights needs to be firstly handled according to the principle with private settlement processes as a priority. If the private settlement process does not work, the public power can intervene in the private fields. And it is true of handling internal disputes of a corporation. The court should respect shareholder's autonomy on corporate affairs, and can intervene in the corporate affairs only when the shareholders fail to settle the disputes. The realization of shareholder autonomy depends on establishing the concept of respecting shareholder autonomy from the perspective of the court and judges.

\footnotetext{
${ }^{15}$ Luo Peixin:Contract Interpretation on Corporation Law , Beijing University Press(8th edition)(2004).P.336.
} 


\title{
Approaches of Judicial Intervention to Corporate Governance
}

\author{
1. Perfecting the system of introducing ordinary civil procedure to corporate governance
}

The Company Law has provisions on protection of substantive rights. In those cases heard through ordinary civil procedure and involving active judicial intervention in the internal decisions of the company and the policymaking of the operator, however, the judicial bodies shall specify and fulfill the mechanism of judicial remedies on substantive rights protection stipulated in the Company Law through the approach of judicial interpretation. The protection of shareholders' rights is an example. In the existing Company Law, considerable protection has been given to the rights of shareholders, but it is relatively conservative and rigid. It lacks a broader remedy and protection mechanism towards those behaviors that are harmful to the rights of shareholders and are not listed in the Company Law. Examples are lacking a mechanism or policy to remove invalid decisions that could damage parts of the shareholders' rights; to confirm or forbid the stock right transfer that could damage the rights of other shareholders; to force the company or other shareholders to purchase the stock of the shareholder who is treated with unfair prejudice from by a resolution of a shareholder meeting. In the framework of existing Company Law, the following situations shall be handled through the ordinary civil procedure by judicial interpretation: the expansion of shareholder derivative action, the confirmation and valuation of targeted share repurchases and the disputes in corporate governance such as the examination of the legality to the rules, regulation and articles of incorporation.

The unfair predjudice remedy mechanism in British Company Law is worth drawing on. Unfair conducts violating the by-laws of the company usually infringe the personal rights of the shareholders. In the Common Law, shareholders exercise their personal rights endowed by the by-laws of the company in a limited way. They cannot file a lawsuit against internal irregularity. British scholars believe that the personal rights of a shareholder shall not be changed or removed by other shareholders and they advocate the protection of shareholder's rights by expanding their rights endowed by the by-laws to other rights within reasonable anticipation. In 1962, the Company Law Committee also known as Jenkins Committee put up a remedy to unfair predjudical actions and proposed to expand the judicial power of the court so as to enable the court to interfere with the affairs of the company by offering remedies to unfair prejudicial actions based on the principle of equity. This proposal was not adopted by the British Company Law until 1980.

Article 994 in British Company Law stipulates that a member of a company may apply to the court by petition for an order on the grounds that the company's affairs are being or have been conducted in a manner that is unfairly prejudicial to the interests of members generally or of some part of its members (including at least himself), or that an actual or proposed act or omission of the company is or would be so prejudicial. ${ }^{16}$ The Jenkins Committee's report points out that unfairness obviously deviates from fair trade standards, violating the fair game rule set by the shareholders who invest

\footnotetext{
${ }^{16}$ The original text is :A member of a company may apply to the court by petition for an order under this Part on the ground(a) that the company's affairs are being or have been conducted in a manner that is unfairly prejudicial to the interests of members generally or of some part of its members (including at least himself), or (b) that an actual or proposed act or omission of the company (including an act or omission on its behalf)is or would be so prejudicial.
} 
money into the company. ${ }^{17}$ The legal precedent considers the test criterion of an unfair prejudice as objective rather than subjective, which means that the applicant is not required to testify whether the behavior of the defendant is out of malice. That is to say the court will affirm the establishment of an unfair prejudice when the result leads to unfair prejudice no matter whether the behavior of the defendant is out of malice or not.

The most commonly used remedies for unfair prejudice are command and writ. When the rights of a shareholder are infringed by unfair conduct, the court will order the company or other shareholders in the company to buy the stock of the shareholder so as to help the shareholder get rid of the awkward situation in which he/she is forced to leave the company. But it is fair only when the stock of the shareholder is not sold at a low price with a discount. ${ }^{18}$ With regard to the base date, the court may choose one from the following options: the date of occurrence of unfair behavior, the date of filing the application, the date of issuing the stock purchase warrant or the date of evaluating the price warrant. The judges' opinions vary from one to another when it comes to choosing the date in a specific case. The judge Vinelott $J$ believed that the evaluation date shall be the date of filing the application on the grounds that on this day the applicant decides to file a lawsuit against the unfair prejudice and the cooperative foundation of the two sides no longer exists on the same day. ${ }^{19}$ The judge Nourse $\mathrm{J}$ believes that the base date shall be the date of issuing the stock purchase warrant on the grounds that it is appropriate to evaluate the basic interest when it is decided to be purchased. ${ }^{20}$

When the unfair infringement is caused by the misconduct of the company itself, the judicial court will issue a writ that the company should perform an act based on the case in which the company is conducting or will conduct an act, or even an omission, if it infringes the shareholder's rights. After the petition for litigation relief, there will be a period of time before the court issues the writ, causing delay of actions and untimely prevention from actual harm of unfair practices to the claimant, like being expelled from the shareholders. Under such a circumstance, the claimant should apply for a temporary command, which will take into full consideration in the decisions, the command effects on the operation order of the company and the protection of the claimant rights. More often, the court will also issue a present-situation-maintenance command for the purpose of guarding the petitioner's rights under a fixed situation.

The adoption of an unfair infringement remedy system, in ordinary civil procedural lawsuits, and granting the court the authority of command (writ) to intervene in the phenomenon of "tyranny of the majority" in the company and protect the property rights of a few shareholders from unfair infringement. As to stock price, the principle should be "it is fair only when one's stock is not sold at a low price with discount"; and as to the date of evaluation, from the perspective of equity, from the day the claimant institutes the legal proceedings to the day he/she submits the application, he/she could not continue to require sharing the profits gained from the proper management of the accused or other managers caused by the breach of trust deeds between the claimant and other shareholders or directors of the company; on the contrary, the claimant shall not assume unfavorable consequences

\footnotetext{
${ }^{17}$ Quoted in John Lowry, The Pursuit of Effective Minority Shareholder Protection: S 459 of the Companies Act 1985, The Company Lawyer Vo1.17 No.3,1996,P.68 .

${ }^{18}$ Fan Yunhui, The Research on British Minority Shareholders Rights Litigation Relief System, China Legal

${ }^{19}$ Re a Company (No 002612 of 1984) (1986) 2 .BCC 99, at P453,492-499.

${ }^{20}$ Re London School of Electronics Ltd (1986).Ch .211.
} 
would be caused by a reduction of management vigor, business hours or the company's reputation resulting from the proceeding. Accordingly, we should fix the date of evaluation on the second day of the proceeding, which is a price indeterminate for both sides. In this way, the value target of ensuring stock equality can be better realized.

\section{Setting up special business procedure for corporate governance}

The civil law countries mostly concentrate on special procedures (non-litigation procedures) to intervene in the company's inner governance ahead of time, as is typically the case in Japan. More specifically, the Japanese Commercial Code has an exclusive chapter on special procedures for judicial intervention into corporate governance. Moreover, in its company law, that came into force in April 2006, there is an additional provision on the non-litigation procedural law of companies, including the dismissal of director, the convening of board of directors and so on. In order to rectify and coordinate the operations of a company, the court intervenes in the company's management via judicial order instead of judgment when dealing with disputes.

According to experience from some countries concentrating on judicial judgment, all disputes possibly arising from the establishment to the dissolution of a company are summarized as 48 types. ${ }^{21}$ However, adopting ordinary civil procedure to solve every company dispute has been obstructed by enormous difficulties and challenges. Existing types of company disputes possess at least the following cases that are available to special procedure when the company fails to obtain favorable judgment through ordinary civil procedure. In terms of function, the special procedure focuses on prevention while the usual procedure is on remedy afterwards and supervision. The special procedure does not aim to make a judgment on the dispute of rights and obligations between parties, but takes some detailed measures to intervene in the company operation. By means of judicial intervention, it is possible to promote the effective operation, prevent unfair behaviors and avoid the infringement of company's as well as the related parties' interests. The cases of special business procedure related to company are as follows:

(1) The case of rights recognition of shareholders such as shareholders request the company to prepare and fill in a roster of the shareholders, sign and issue an investment certificate, and register the modification of shares.

(2) The case of shareholder's right to be informed; specifically including: reviewing and duplicating company materials, reviewing the financial reports; requesting the company to disclose the information about remunerations received by the directors, supervisors and senior managers. The public shareholders can request the company to disclose the information about business activities, major acquisition and litigation.

(3) The case of dispute on the convening of shareholders' assembly, board of directors and board of supervisors; including the cases like irregular convening, negative omission, and if the entitled convener appeals to judicial support to conducting a temporary board meeting in accordance with the law.

(4) The case of dispute on appointment and dismissal of director, supervisors and senior Managers;

\footnotetext{
${ }^{21}$ Xi Xiaoming, Jin Jianfeng: ResearchonTheoryandPractice of CorporationLitigation, the People's Court Press, 2008.
} 
(5) The case of exercising power; including supervisors exercise of authority in accordance with law under the circumstance where the company actively participates in, eliminates obstacles and offers financial support.

(6) The case of disputes on share valuation; including price dispute in share repurchase and share dispute where the major shareholder is forced to purchase the minor shareholder's share under the specific instance.

(7) The case of dispute on the liquidation of company; the following functions during the process of liquidation may be exercised: liquidating the properties of the company; notifying creditors by mail or public announcement; handling and liquidating the unfinished business of the company; paying off the outstanding taxes and the taxes incurred in the process of liquidation; distributing the remaining properties; and participating in the civil proceedings of the company. The liquidation specialists decide when the special procedure should be involved.

In judicial practices, the Supreme People's Court of China has made special provisions on part of the said cases, like the liquidation of company by judicial interpretation. This provision, however, is still exercised within the framework of existing ordinary civil procedure. A professional and systematic special procedure needs to be further established and improved.

This paper argues that China should learn the concepts, institutions and measures of judicial intervention to company governance from western countries and build a non-litigation intervening mechanism paired with China's civil action system to solve company disputes. Courts should be entrusted some rights to punish violating and unfair conduct by company staff, including the right of judicial curb (ban), the right of invalidation, the right of judicial selection, the right of judicial dismissal and the right of judicially convening stockholders' meeting. Thereby, it is possible to defuse injustice and unfairness, maintain the normal order and enhance the efficiency of corporate governance.

\section{Drawing support from judicial experts}

Judicial officials should have a profound professional knowledge of corporate governance, and the intrinsic nature of company law as putting judicial intervention into company governance. In the face of professional problems related to company affairs, it is necessary to draw the experts of this field to participate in a collegiate bench, ensuring the quality of judicial intervention and exerting positive effect of the judicature on corporate governance.

In Delaware of the US the cases of company law are exclusively accepted by the court of chancery, where judges spend 70 percent of their time on company affairs. Due to having a professional background in the field of capital markets before getting into the court, these judges gain experience and are honored as the most learned people who deal with company affair in the US. In the court system of Britain, there are usually 12 judges from court of the chancery to tackle company affairs, which is a better reflection of the key mechanism of company litigation than that of North America. ${ }^{22}$

\footnotetext{
${ }^{22}$ Brian R. Cheffins: Company Law: Theory, Structure and Functioning ,translated by Lin Weihua, Law Press China, 2001, P. 1337.
} 
Existing judicial resources are limited, especially the professional level of common judges cannot meet the requirements that case law expects. For example, a court's discretionary power is not exercised well. Therefore courts should set up independent and special commercial courts and shift the hearing model to "consulting specialists". Considering the high professional skill involved in the case of corporate governance, the court in the domicile of a company should be given a clear exclusive jurisdiction and a listed company should be under the jurisdiction of the local intermediate people's court.

These measures guarantee that cases are accepted and administered more easily and effectively. At the same time, other feasible measures should be taken to include "specialist consultants", including organizing the jury, drawing experts in the field of law, accounting and administration of a company, as well as drawing highly respected people from enterprises and chambers of commerce.The speed to modify company law is much slower than that of unveiling of judicial interpretation, on the basis of which the Supreme People's Court of China deals with a certain case, causing a lack of provision of company law. In face of boundless issues in practice, the Supreme People's Court and the supreme courts of various regions direct the judiciary to moderately intervene in company governance by the guidance of precedents, which undoubtedly is a relatively appropriate and low-cost way. 
